\title{
Influence of Landfill Leachate on Organic Matter Removal in Activated Sludge and Activated Sludge with Carrier Processes
}

\author{
Fábio Campos ${ }^{1^{*}}$ \\ https://orcid.org/0000-0002-8117-789X
}

\author{
Rodrigo de Freitas Bueno ${ }^{2^{*}}$ \\ https://orcid.org/0000-0002-6274-3278
}

Roque Passos Piveli ${ }^{*}$

https://orcid.org/0000-0003-0653-0603

\begin{abstract}
1 University of São Paulo, Polytechnic School, Department of Hydraulic and Environmental Engineering, São Paulo, Brazil; ' ${ }^{2}$ Federal University of ABC, Center for Engineering, Modeling and Applied Social Sciences, Santo André, São Paulo, Brazil.
\end{abstract}

Received: 2018.07.25; Accepted: 2020.02.13.

*Correspondence: fcampos@usp.br; tel.: +55-11-30915582 (F.C.); rodrigo.bueno@ufabc.edu.br (R.F.B.); rppiveli@usp.br (R.P.P.).

\section{HIGHLIGHTS}

- This paper presents a he behavior of a hybrid process treating landfill leaching together with sewage.

\begin{abstract}
This study assessed the performance of two pilot units, a conventional activated sludge (CAS) and an Integrated Fixed-Film Activated Sludge (IAS), in the treatment of leachate from sanitary landfill combined with domestic sewage, with the aim of removing organic substances. In order to assess the possible impacts on treatment, three experimental phases were designed using influent leachate contributions of $5 \%, 10 \%$, and $20 \%$ of the total BOD load. Overall, the results showed that no significant changes in the behavior of biological processes. The IAS unit presented average BOD removal efficiencies of above $88 \%, 87 \%$ and $80 \%$ for the three leachate load contributions of $5 \%, 10 \%$ and $20 \%$ studied. The CAS unit presented lower average efficiency with a $5 \%$ leachate contribution (64\%), but displayed a similar performance to the IAS unit in the other phases $(82 \%$ and $80 \%)$; similar quantitative aspects were observed for both treatment processes with regards to biomass composition analysis. The kinetic coefficients related to heterotrophic metabolism did not indicate negative effects on treatment efficiency as a result of the increase in leachate addition, with values of 2.8; 2.8 and $2.7 \mathrm{~d}^{-1}$ obtained respectively for each phase with the CAS unit, and 2.0; 1.5 and $1.6 \mathrm{~d}^{-1}$ with

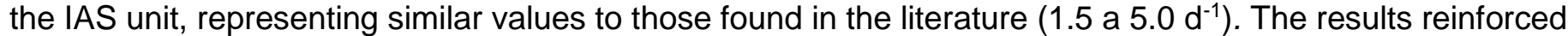
the conclusion that the leachate load introduced did not cause inhibition or significant alterations to heterotrophic metabolism, and, therefore, to the removal of organic matter.
\end{abstract}

Keywords: combined treatment of leachate and domestic sewage; integrated fixed-film activated sludge; removal of organic matter. 


\section{INTRODUCTION}

Landfill leachate is wastewater of difficult treatability, due to the presence of biodegradable organic matter that varies in concentration over time, recalcitrant organic matter, toxic inorganic compounds, and high concentrations of ammoniacal nitrogen. A common solution adopted in many countries is to dispose of the leachate into sewage treatment plants so that the dilution of inhibiting substances allows biochemical processes to occur more stably and efficiently [1]. However, if very large volumes or unequalized loads of leachate are introduced into the sewage treatment plant (STP), this may cause irreversible impairments to processes. The low operating cost, as well as the use of an existing structure, reinforces the use of this alternative. However, regarding the quality of the effluent generated by the combined treatment of leachate and wastewater, it is possible that the parameters commonly used to characterize the efficiency of the treatment in the removal of organic compounds, such as BOD, COD, and TOC, do not allow exact distinction between biodegradable organic matter and the recalcitrant matter [2,3,4].

A study of four STPs in Sao Paulo concluded that further studies are needed to fully understand the implications arising from the combined treatment of leachate and sewage, including the effects of toxicity on biological processes and the quality of sludge and effluent from the treatment process [5]. Experiments involving batch activated sludge with varying hydraulic retention times (HRT) and leachate proportions in the sewage ranging from $5 \%$ to $25 \%(\mathrm{v} / \mathrm{v})$, achieved $97.5 \%$ organic matter removal with a 2 -day HRT [6]. In experiments with the treatment of leachate from the Gaziantep (Turkey) landfill mixed with sewage in a batch activated sludge process, with ratios ranging from 5 to $20 \%(\mathrm{v} / \mathrm{v})$, it was concluded that when the leachate percentage is over $20 \%$ of the treated influent wastewater or equal to $50 \%$ of the initial COD load, the treatment efficiency is compromised [7]. A study conducted using the activated sludge process with leachate proportions ranging from $1 \%$ to $16 \%$ by volume, mixed with sewage, found that BOD and COD values increased in the final effluent according to the proportion of leachate added. This increase is possibly due to phosphorus deficiency and the addition of non-biodegradable organic load from the leachate [8]. The use of an activated sludge reactor operating in batch sequence in the laboratory for the treatment of combined effluents obtained $70 \%$ to $98 \%$ BOD removal and $35 \%$ to $50 \%$ total nitrogen removal with a $10 \%$ leachate (BOD 2000-4700 mg. $\mathrm{L}^{-1}$, COD 4700-12000 mg. $\mathrm{L}^{-1}$ and $\mathrm{N}-\mathrm{NH}_{3}$ 405-920 mgN.L ${ }^{-1}$ ) percentage in the mix volume [9]. Some researchers have recommended leachate to wastewater volume ratio of below $2 \%$. Adding large volumes of leachate to sewage treatment systems may further result in treated effluents with high concentrations of organic matter and ammoniacal nitrogen [10]. One of the new treatment technologies developed in recent decades is a hybrid process called Integrated Fixed Film Activated Sludge (IFAS), which has not yet been fully exploited in the treatment of sanitary landfill leachate. The IFAS process promotes biomass growth in the aeration tanks of activated sludge systems in order to increase their capacity and improve performance. In this process, the concentration of active solids in the biological sludge can be significantly increased by the introduction of mobile biomedia into an activated sludge system $[11,12]$. Highly specialized biomass builds up inside the biomedia for each type of condition imposed on the reactor, regardless of the sludge age in relation to the suspended biomass. The contribution of the adhered biomass in the support environment means that lower concentrations of suspended biomass are required in the reactor, thus reducing the load of suspended solids in the secondary clarifiers and preventing negative effects on the effluent clarification process $[13,14,4]$.

The IFAS process can be considered as a good alternative when the goal is to increase the treatment capacity of pre-existent activated sludge systems. Other situations include the incorporation of nutrient removal, particularly of nitrogen, since the nitrifying bacteria retained in the biofilm allow the system to operate with shorter SRT, thereby reducing treatment costs [15,3].

A study involving treatment of leachate from an old landfill in Northern Italy used a combined MBR-MBBR system with $37.5 \%$ tank capacity in the MBBR. The system was operated in order to observe nitrification, obtaining approximately $90 \%$ of ammonia removal with application rates ranging from 5 to $120 \mathrm{gN}$ TKN.kgTSS-1.d ${ }^{-1}$ [16]. A study group evaluated an MBBR system with $60 \%$ tank capacity, occupied with biomedia and operating with HRT ranging from 2 to 5 days and at $80 \%$ of dissolved oxygen (DO) saturation, in the treatment of leachate from the Hyllstofia (Sweden) landfill, in operation since 1975. During the study, up to $98 \%$ of nitrification was obtained with application rates of up to $11 \mathrm{~g} \mathrm{~N}-\mathrm{NH}_{4}{ }^{+} \cdot \mathrm{m}^{-3} \cdot \mathrm{h}^{-1}$. The researchers concluded that rates of up to $40 \mathrm{~g} \mathrm{~N}-\mathrm{NH}_{4}{ }^{+} \cdot \mathrm{m}^{-3}$ reactor ${ }^{-1} \cdot \mathrm{h}^{-1}$ could be applied without the risk of biomass loss or of compromising the treatment efficiency. This study aimed to evaluate the performance of two bioreactors, focused on the removal of organic matter, as well as on the kinetic behavior of the treatment processes [17]. The first system operated as a conventional activated sludge process, and the second as an IFAS process, each receiving the mixture of leachate loads combined with domestic sewage. 


\section{MATERIAL AND METHODS}

The research was conducted using a pilot-scale experiment with the operation of two activated sludge bioreactors. The bioreactors were made of acrylic sheet and differed from each other due to the introduction of mobile biomedia into one of them for the development of attached biomass, therefore configuring an IFAS hybrid system. In this study, the pilot unit operating as a conventional activated sludge process is referred to as CAS, while the hybrid system is referred to as IAS. The aeration tank was divided into two compartments. The first had a useable volume of $270 \mathrm{~L}$, was equipped with a mixer, and operated as an anoxic predenitrification chamber. The second compartment had a useable volume of $800 \mathrm{~L}$ and functioned as an aerated chamber, with four thin membrane bubble diffusers installed at its bottom to distribute the air provided by the compressor and maintain the DO concentration within the interval of $1.0-3.0 \mathrm{mg} \cdot \mathrm{L}^{-1}$ in the CAS pilot, and 3.0-4.0 mg. $\mathrm{L}^{-1}$ in the IAS pilot. The secondary clarifier had a circular section from a top-view reference, with a wall scraper driven by an electric motor, a surface area of $0.785 \mathrm{~m}^{2}$ and useful volume of $1.47 \mathrm{~m}^{3}$. The pilot units also had two elevating sets, one to return the sludge from the secondary clarifier to the anoxic chamber, and the other to recycle the internal mixed liquor from the aeration tank to the anoxic chamber. Biomedia was added to both bioreactor chambers in the IAS pilot. The K1 product, manufactured by Anox Kaldnes ${ }^{\circledR}$ and currently owned by Veolia Water group was used, with a specific surface area (protected) of $300 \mathrm{~m}^{2} \cdot \mathrm{m}^{-3}$ of support material. The anoxic and aerobic chambers were filled with $30 \%$ and $50 \%$ of biomedia, respectively. To take readings, $\mathrm{pH}, \mathrm{DO}$, and temperature sensors were installed in the bioreactors. Figure 1 provides an overview of the pilot units.

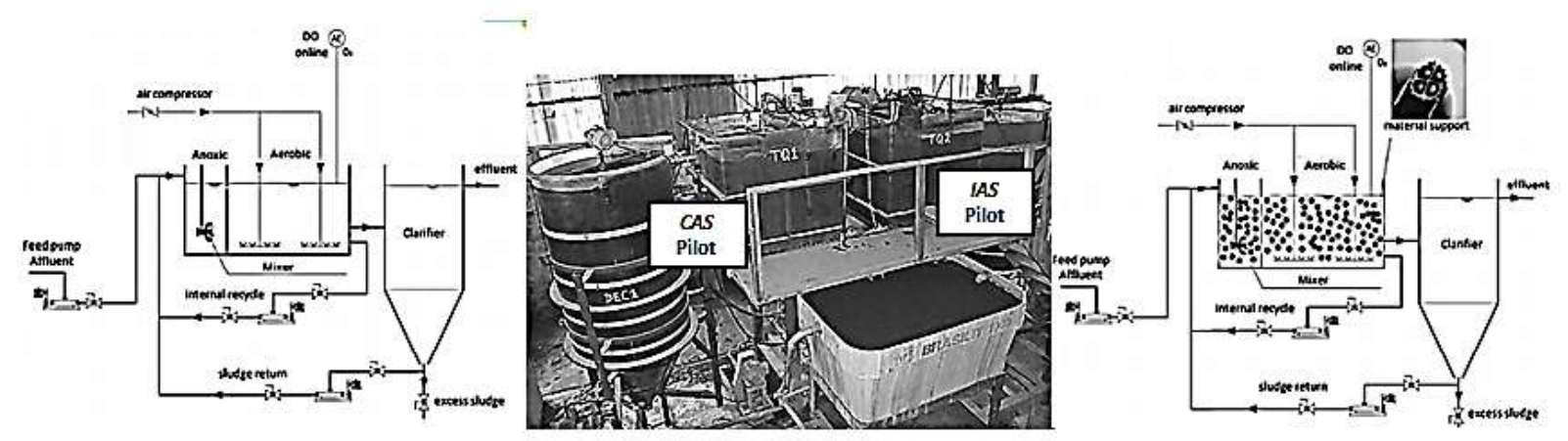

Figure 1. Overview of the Pilot Units.

The leachate used throughout this study came from the Caieiras Landfill (CTR-Caieiras), which has been in operation since 2002. The sewage came from the Residential Complex of the University of São Paulo (CRUSP) and went through preliminary treatment (screening, grit chamber, and degreaser) before entering the pilot unit.

Three experimental phases were established to comparatively evaluate the possible impacts produced by the leachate loads in the two systems. The phases had different BOD load percentages as a result of different leachate contributions $(5 \%, 10 \%$, and $20 \%)$ in the total load while all other conditions were kept constant.

The pilot units eliminated excess activated sludge so as to achieve an overall solids retention time (SRT) of nine days based only on the concentration of suspended biomass (VSS), and, discounting the anoxic chamber fraction, resulting in 6-day-old aerobic sludge. From the initial sewage characterization, a feed rate of $2.1 \mathrm{~m}^{3} . \mathrm{d}^{-1}$ was established for the CAS pilot unit and of $1.7 \mathrm{~m}^{3} \cdot \mathrm{d}^{-1}$ for the IAS pilot unit, which corresponds to a food/microorganisms (F/M) ratio of $0.2 \mathrm{kgBOD} \mathrm{kgVSS}^{-1} . \mathrm{d}^{-1}$ and an HRT of $0.48 \mathrm{~d}$. Both the decanted sewage and the landfill leachate, as well as the effluents produced by the processes, were characterized twice a week by determining the following variables: total and soluble $\mathrm{BOD}_{5.20}$, total and soluble COD. As well as being monitored by the sensors, the sludge from the reactor was characterized in terms of Total, Fixed, and Volatile Suspended Solids. All of the analytical methodologies used followed the $21^{\text {st }}$ edition of the Standard Methods for Examination of Water and Wastewater [18]. To determinate attached biomass concentrations in the IAS pilot, 35 biomedia units were initially separated in a Falcon tube, occupying a volume of $40 \mathrm{~mL}$. The biomass was then released by scraping the biomedia with a toothbrush. After this step, the mass of solids was determined through gravimetric analysis. This value was used to obtain the concentration in terms of $\mathrm{mg} \cdot \mathrm{L}^{-1}$, and the mass was divided by the biomedia volume $(40 \mathrm{~mL}$. To obtain the concentration in terms of $\mathrm{g} \cdot \mathrm{m}^{2}$ the mass was divided by the surface area $\left(0.012 \mathrm{~m}^{2}\right)$ of the biomedia related 
to the $40 \mathrm{~mL}$ volume. To evaluate the kinetic behavior of the processes in each phase of the experiment, respirometric tests were performed with the sludge from both aeration tanks. For this purpose, a Beluga S32c device was used. This is an open and semi-continuous type device developed by the Department of Electrical Engineering at UFCG - Federal University of Campina Grande [19]. Table 1 lists the equations used for determining the kinetic coefficients concerning the growth of the heterotrophic bacteria.

Table 1. Equations for determining the kinetic coefficients of heterotrophic bacteria

\begin{tabular}{cc}
\hline Symbol & Equations \\
\hline OUR & OUR $=\frac{d O}{d t}=\frac{D O_{\max }-D O_{\text {min }}}{t_{1}-t_{0}}$ \\
$\mathrm{Xa}_{\mathrm{a}}$ & $X_{a}=\frac{O U R_{\text {end }}}{\left[f_{c v} *(1-f) * b_{h}\right]} * 24$ \\
$\mathrm{~K}_{\mathrm{ms}}$ & $K_{m s}=3 * \frac{O U R_{\text {exo }}}{X_{a}} * 24$ \\
$\mu_{\max }$ & $\mu_{\max }=Y_{h} * K_{m s}$
\end{tabular}

In which:

OUR = oxygen uptake rate $\left(\mathrm{mgO}_{2} \cdot \mathrm{L}^{-1} \cdot \mathrm{h}^{-1}\right)$;

OURend $=$ oxygen consumption rate in endogenous phase $\left(\mathrm{mgO}_{2} \cdot \mathrm{L}^{-1} \cdot \mathrm{h}^{-1}\right)$;

OURexo $=$ exogenous oxygen consumption rate $\left(\mathrm{mgO}_{2} \cdot \mathrm{L}^{-1} \cdot \mathrm{h}^{-1}\right)$;

$\mathrm{f}_{\mathrm{cv}}=\mathrm{COD}$ conversion factor for active material (adopted: $1.5 \mathrm{mgCOD} \mathrm{mgVSS}^{-1}$ );

$\mathrm{f}=$ activated sludge fraction that remains as endogenous residue (adopted: 0.2 );

$b_{h}=$ endogenous decay coefficient (adopted: $0.24 \times 1.04^{(T-20)}$ );

$\mathrm{K}_{\mathrm{ms}}=$ specific speed of substrate utilization ( $\left.\mathrm{mgCOD} \mathrm{mgX}_{\mathrm{a}}{ }^{-1} \cdot \mathrm{d}^{-1}\right)$;

$\mathrm{X}_{\mathrm{a}}=$ activated sludge concentration (mgVSS $\left.\mathrm{A}_{\mathrm{A}} \mathrm{L}^{-1}\right)$;

$\mathrm{Y}_{\mathrm{h}}=$ coefficient of cellular synthesis (adopted: $0.45 \mathrm{mgX}_{\mathrm{a}} \times \mathrm{mgCOD}^{-1}$ );

\section{RESULTS}

\section{Characterization of the influent, application rates and physicochemical parameters of the process}

The characterization of the decanted sewage in the $1^{\text {st }}, 2^{\text {nd }}$ and $3^{\text {rd }}$ phases provided mean BOD compositions of 210,200 and $238 \mathrm{mgO}_{2} \cdot \mathrm{L}^{-1}$ and mean COD compositions of 493,435 and $441 \mathrm{mgO}_{2} \cdot \mathrm{L}^{-1}$, respectively. Concerning nitrogenous variables, mean TKN values of 81,85 and $65 \mathrm{mgN}^{-\mathrm{NH}_{4}}{ }^{+} . \mathrm{L}^{-1}$ were obtained for each phase, respectively, and $\mathrm{NH}_{4}{ }^{+}$values of 65,74 and $51 \mathrm{mgN}-\mathrm{NH}_{4}{ }^{+}$. $\mathrm{L}^{-1}$ were obtained for the $1^{\text {st }}, 2^{\text {nd }}$ and $3^{\text {rd }}$ phases, respectively. The results show that the decanted sanitary sewage remained relatively stable throughout the three experimental phases, possibly because the raw sewage discharge line does not receive contributions from rainwater and does not present any infiltration. Comparing the average results with typical values in the literature, both BOD and COD were verified to be compatible with average values for sewage, whereas the TKN and $\mathrm{NH}_{4}{ }^{+}$values are similar to those of concentrated sewage. It is very probable that this unusual composition, with high values for nitrogen compounds, is caused by the contribution of the sewage produced by the central restaurant with restrooms, providing a greater volume of urine. Analysis of the composition of the sanitary landfill leachate used during the study resulted in mean BOD values of 1369 , 1170 and $2042 \mathrm{mgO}_{2} \cdot \mathrm{L}^{-1}$ and $\mathrm{COD}$ values of 3982,3845 and $4551 \mathrm{mgO}_{2} \cdot \mathrm{L}^{-1}$ for each phase of the study,

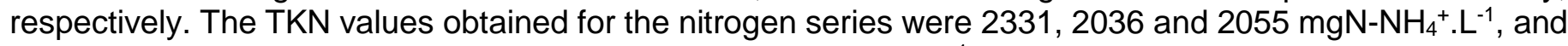
for ammoniacal nitrogen were 2075,1826 and $1860 \mathrm{mgN}-\mathrm{NH}_{4}{ }^{+} . \mathrm{L}^{-1}$, respectively. It can be observed that the results obtained for the $B O D$ and $C O D$ variables classify it as leachate from an intermediate landfill, with a $\mathrm{BOD} / \mathrm{COD}$ ratio of between 0.3 and 0.4 ; while the results obtained for $\mathrm{TKN}$ and $\mathrm{NH}_{4}{ }^{+}$are typical of new landfill leachate. Table 2 shows the mean values calculated for the characterization of the real influent throughout the research, obtained by mass balance. 
Table 2. Influent characterization (sewage + leachate)

\begin{tabular}{|c|c|c|c|c|c|c|c|c|c|}
\hline \multirow{2}{*}{ Variable } & \multicolumn{3}{|c|}{$\begin{array}{c}\text { 1st phase } \\
\text { (5\% leachate) }\end{array}$} & \multicolumn{3}{|c|}{$\begin{array}{c}\text { 2nd phase } \\
(10 \% \text { leachate })\end{array}$} & \multicolumn{3}{|c|}{$\begin{array}{c}\text { 3rd phase } \\
\text { (20\% leachate) }\end{array}$} \\
\hline & $n$ & Avg & SD & $\mathrm{N}$ & Avg & SD & $\mathrm{n}$ & Avg & SD \\
\hline $\begin{array}{l}\text { COD total } \\
\left(\mathrm{mgO}_{2} \cdot \mathrm{L}^{-1}\right)\end{array}$ & 19 & 522 & 93 & 8 & 531 & 51 & 20 & 614 & 95 \\
\hline $\begin{array}{l}\mathrm{BOD}_{5,20} \text { total } \\
\left(\mathrm{mgO}_{\left.2 . \mathrm{L}^{-1}\right)}\right.\end{array}$ & 19 & 220 & 22 & 8 & 216 & 6 & 20 & 286 & 51 \\
\hline $\begin{array}{l}\text { TKN } \\
\left(\mathrm{mgN} . \mathrm{L}^{-1}\right)\end{array}$ & 19 & 107 & 18 & 8 & 157 & 17 & 20 & 214 & 48 \\
\hline $\begin{array}{l}\mathrm{N}-\mathrm{NH}_{4}+ \\
\left(\mathrm{mgN}^{+} \mathrm{NH}_{4}{ }^{+} . \mathrm{L}^{-1}\right)\end{array}$ & 19 & 82 & 5 & 8 & 108 & 11 & 20 & 125 & 28 \\
\hline $\begin{array}{l}\text { Alcalinity } \\
\left(\mathrm{mgCaCO}_{3} \cdot \mathrm{L}^{-1}\right)\end{array}$ & 19 & 228 & 50 & 8 & 369 & 26 & 20 & 568 & 154 \\
\hline
\end{tabular}

The data in Table 2 confirms how a progressive leachate load increase influences the concentration of the variables related to organic and nitrogenous matter and the alkalinity of the influent to the pilot units.

With regards to the volumetric organic load (VOL), and the volumetric nitrogen load (VNL) applied to the processes, the results obtained are typical for biological processes, remaining in the range of 0.48 to 0.72 $\mathrm{kgBOD} \cdot \mathrm{d}^{-1}$ and 0.35 to $0.89 \mathrm{kgN} \cdot \mathrm{m}^{3} \cdot \mathrm{d}^{-1}$, respectively.

Regarding the results for the physicochemical parameters obtained from the sensors installed in the pilot units, the average temperature was $21 \pm 3{ }^{\circ} \mathrm{C}$; for $\mathrm{pH}$, the average for the CAS unit was $7.2 \pm 0.6$ and for the IAS unit was $7.7 \pm 0.6$. For the DO concentration in the aeration tanks, the average values were $2.1 \pm 0.4$. $\mathrm{mgO}_{2} / \mathrm{L}$ and $3.3 \pm 0.5 \mathrm{mgO}_{2} / \mathrm{L}$ for the CAS and IAS pilots, respectively.

\section{Biomass characterization}

\section{Suspended biomass in the CAS and IAS pilot units}

Regarding the suspended biomass fraction, it was possible to work with the VSS values in the sludge of both aeration tanks in the range of 2000 to $5000 \mathrm{mg} \cdot \mathrm{L}^{-1}$, as indicated in the literature [20]. Table 3 presents statistical details of the values obtained for the concentrations of volatile suspended solids (VSS) from the aeration tanks of both pilot units.

Table 3. Descriptive Statistics of the Results of the VSS Sludge Aeration Tank.

\begin{tabular}{|c|c|c|c|c|c|c|}
\hline & \multicolumn{2}{|c|}{$\begin{array}{c}\text { 1st phase } \\
\text { (5\% leachate) }\end{array}$} & \multicolumn{2}{|c|}{$\begin{array}{c}\text { 2nd phase } \\
(10 \% \text { leachate })\end{array}$} & \multicolumn{2}{|c|}{$\begin{array}{c}\text { 3rd phase } \\
(20 \% \text { leachate) }\end{array}$} \\
\hline & $\begin{array}{l}\text { CAS } \\
\text { mg.t-1 }\end{array}$ & $\begin{array}{l}\text { IAS } \\
\text { mg.L-1 }\end{array}$ & $\begin{array}{l}\text { CAS } \\
\text { mg.t-1 }\end{array}$ & $\begin{array}{l}\text { IAS } \\
\text { mg.L-1 }\end{array}$ & $\begin{array}{l}\text { CAS } \\
\text { mg. } \text { L }^{-1}\end{array}$ & $\begin{array}{l}\text { IAS } \\
\text { mg.L-1 }\end{array}$ \\
\hline Num. Data & 19 & 19 & 8 & 8 & 20 & 20 \\
\hline Median & 3120 & 2450 & 3065 & 2090 & 3570 & 3235 \\
\hline Average & 2954 & 2319 & 2953 & 2225 & 3610 & 3099 \\
\hline Minimum & 1230 & 1390 & 2290 & 1650 & 2520 & 1850 \\
\hline Maximum & 4020 & 3410 & 3390 & 3310 & 4820 & 4680 \\
\hline Coef. Var. & 0,26 & 0,28 & 0,13 & 0,24 & 0,19 & 0,24 \\
\hline Standard Dev. & 762 & 649 & 377 & 534 & 687 & 752 \\
\hline
\end{tabular}

In relation to the sludge from the return line, average values between $3000-6000 \mathrm{mgVSS} . \mathrm{L}^{-1}$ were obtained in both pilot units. This result demonstrated that the leachate load introduced did not affect the formation of the suspended biomass in any of the experimental phases.

\section{Adhered biomass in the IAS pilot unit}

A specific methodology was used to quantify the analysis of adhered biomass in the IAS pilot unit, considering the specific surface area of the Kaldnes ${ }^{\circledR} \mathrm{K} 1$-type carrier media $\left(300 \mathrm{~m}^{2} \cdot \mathrm{m}^{-3}\right)$. The study obtained VSS values of $12.9,7.2$ and $12.6 \mathrm{gVSS} . \mathrm{m}^{-2}$, respectively, for biomedia surface area in the three experimental phases. These values are within the range found in the literature: 2 to 44 gVSS.m ${ }^{-2}[21,22,23,24]$. Figure 2 demonstrates the historical series of VSS concentrations in both suspended and attached biomass. 


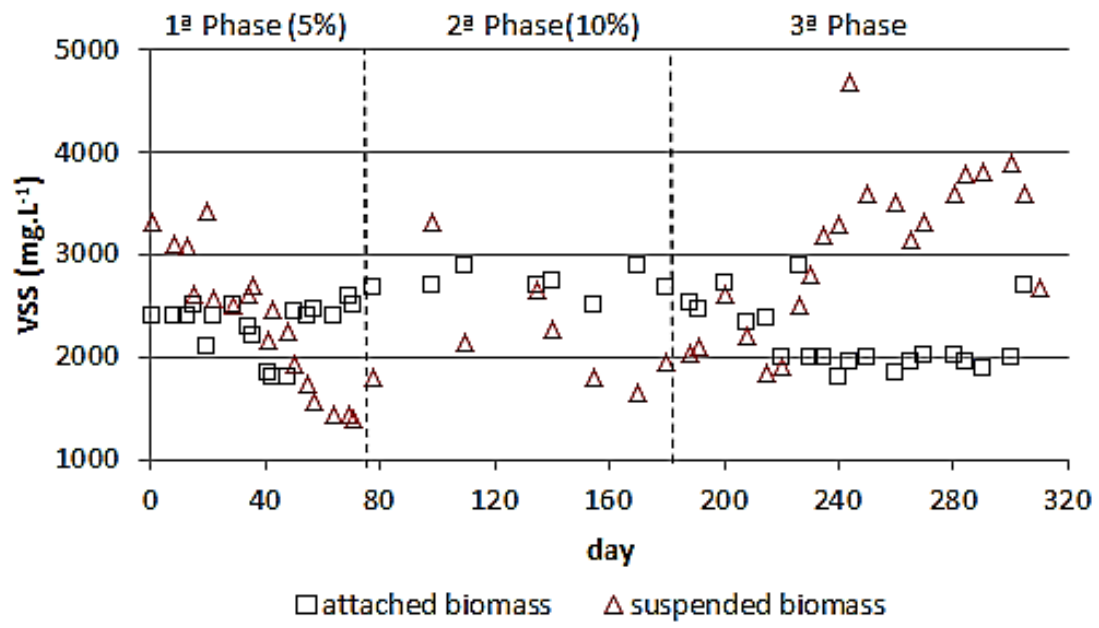

Figure 2. Historical VSS series referring to suspended and attached biomass (IAS Pilot).

By analyzing Figure 2, it can be observed that there was similar behavior in suspended and adhered VSS concentrations throughout the study, except in the $3^{\text {rd }}$ phase, where the VSS values increased while the adhered biomass values decreased. We can hypothesize that operational problems that occurred during this phase, due to the malfunctioning of the wall scraper in the secondary decanter, may have caused increased biomass detachment from the biofilm.

The contribution of VSS to the adhered biomass resulted in corresponding percentage increases of $75 \%$, $43 \%$ and $55 \%$ for each phase of the study, concerning the biomass in suspension. It should be noted that the biomedia that was used in this study had a specific surface area of $300 \mathrm{~m}^{2} / \mathrm{m}^{3}$.

The evaluation of hybrid systems, such as the IFAS process used in the IAS pilot unit, must encompass the specific contribution of each adhered or suspended biomass fraction in the treatment process. To estimate substrate consumption by biofilm area, the values used were those suggested by WEF MOP n. 8 (2009), which were based on the kinetic model of the process, as shown in Table 4 [25], thus, linear interpolation for the 6-day old aerobic sludge used in the IAS pilot unit gave results of up to $12.5 \%$ of COD removal in function of the adhered biomass. Based on these results, the COD application rates per area of biofilm were calculated. Figure 3 illustrates the results obtained throughout the study.

Table 4. Percentages of COD removal in biofilms at $15^{\circ} \mathrm{C}$

\begin{tabular}{cc}
$\begin{array}{c}\text { SRT } \\
\mathbf{d}^{(*)}\end{array}$ & $\begin{array}{c}\text { COD } \\
(\%)\end{array}$ \\
\hline 2 & 50 \\
4 & 25 \\
8 & -
\end{tabular}

$\left.{ }^{*}\right)$ in relation to the suspended biomass

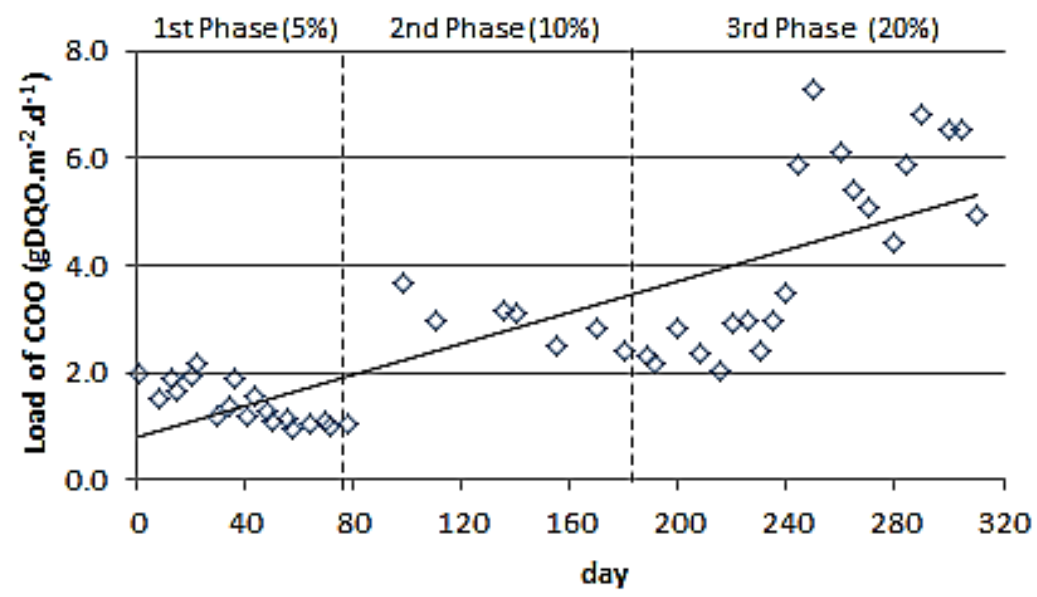

Figure 3. COD application rates per biofilm area (IAS pilot unit).

The behavior of the biofilm in relation to the application of the superficial organic load showed negative variability during the first phase but recovered in the subsequent phase and finally presented positive 
variability with increasing leachate load contribution. It should be noted that the results indicate substantial organic matter removal efficiency with COD loads of up to $8 \mathrm{gCOD} \cdot \mathrm{m}^{-2} \cdot \mathrm{d}^{-1}$. By evaluating the surface loads imposed on the process and obtained from the leachate portion of the influent composition, it can be stated that the process was not inhibited.

\section{Organic matter removal}

The system was able to maintain a stable operation with regards to organic matter removal over the three phases of the experiment. Table 5 displays the average results for $B O D_{\text {total }}$ and $C O D_{\text {total }}$ for both raw and treated sewage over the three phases, and in terms of the efficiency of the processes.

Table 5. Average values for $\mathrm{BOD}_{\text {total }}$ and $\mathrm{COD}_{\text {total }}$

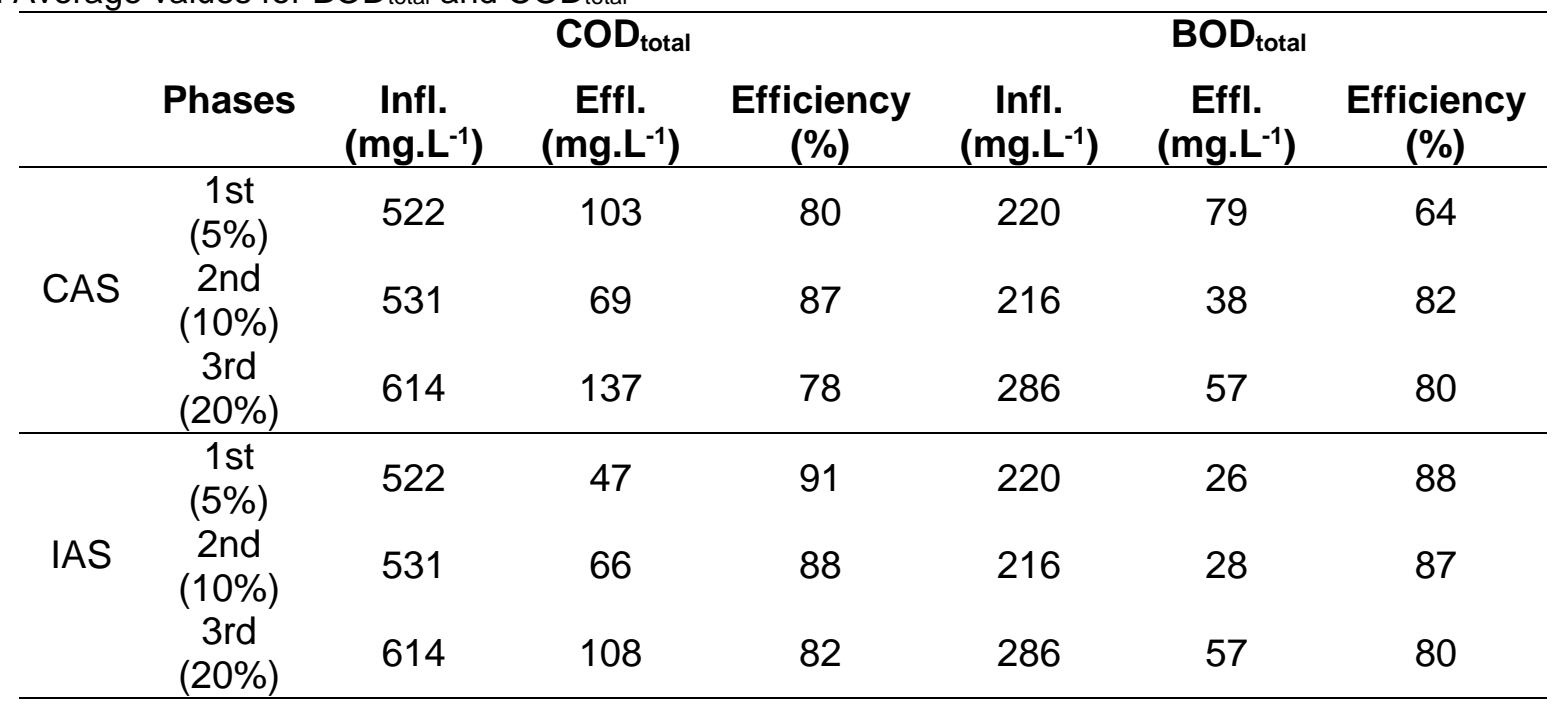

In general, the results obtained for organic matter removal were noticeably constant, but lower than is commonly expected in biological processes in activated sludge. In a study conducted with the same pilot units operating with an overall SRT of 9 days and F/M ratio of $0.2 \mathrm{kgCOD} . \mathrm{kgVSS} . \mathrm{d}^{-1}$, with no leachate contribution, the BOD removal rates were approximately $69 \%$ for the CAS pilot unit and $88 \%$ for the IAS pilot unit. The values for COD were $79 \%$ for the CAS and $90 \%$ for the IAS [19]. These results are similar to those obtained in this study. This result allows us to infer that the low yield is not due to the leachate load introduction and may be explained by other factors, such as the loss of solids in the final effluent. Due to operational problems with the scraper of the secondary decanters, a continuous drag of suspended solids was observed.

An alternative to evaluate the efficiency of colloidal organic matter removal and eliminate the interference caused by the loss of suspended solids in the effluent is to measure the soluble BOD portion in the final effluent. Analysis of soluble BOD in the effluent resulted in mean values of 15,21 and $26 \mathrm{mgO}_{2} . \mathrm{L}^{-1}$ for the CAS pilot unit, in the 1st, 2nd and 3rd phases, respectively, and 9, 12 and $27 \mathrm{mgO}_{2} \cdot \mathrm{L}^{-1}$ for the IAS pilot unit. The analysis revealed good efficiency and proved that the introduction of increasing leachate loads did not affect the results. Figure 4 shows the historical values for the following variables obtained during the study, for both pilot units: $\mathrm{BOD}_{\text {soluble; }} \mathrm{BOD}_{\text {total }}$ and VSS in the effluent. 
CAS Pilot

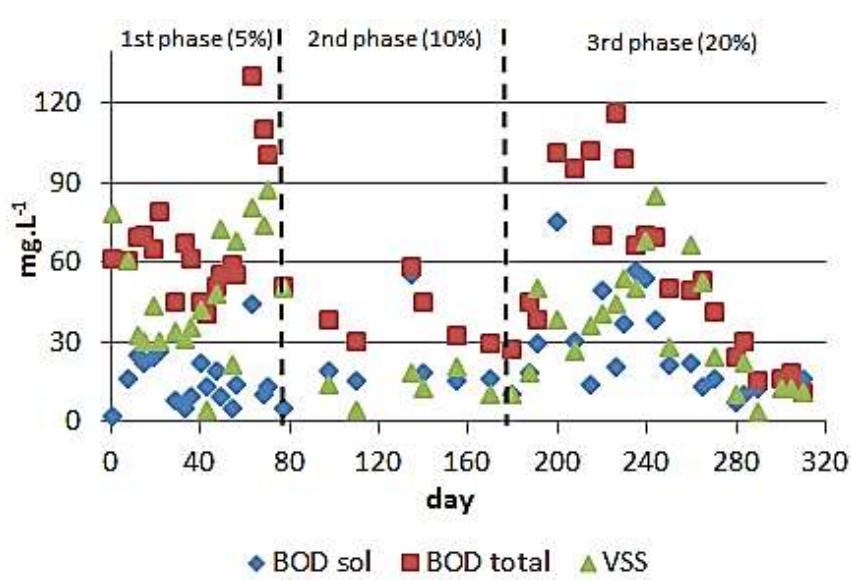

IAS Pilot

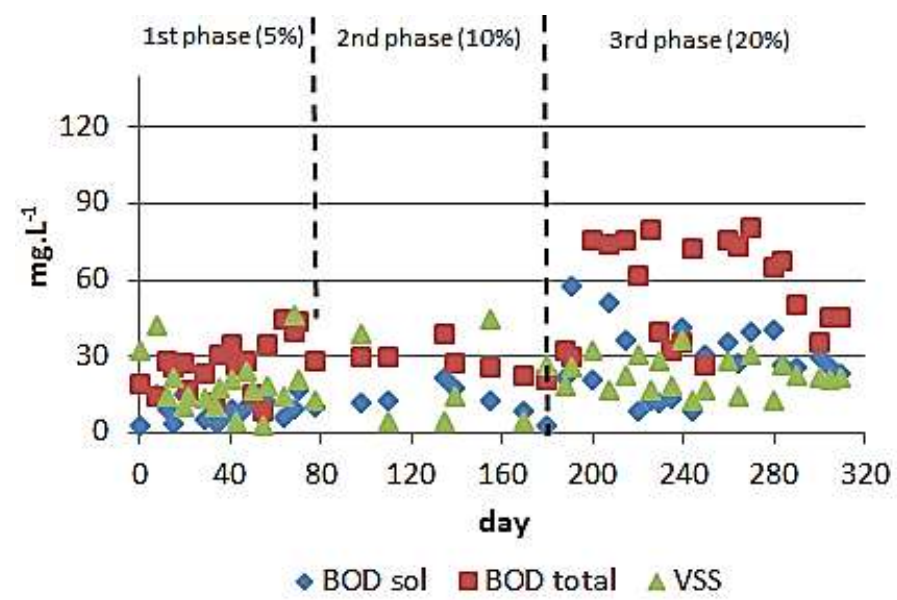

Figure 4. Historical Series of the Results of the $\mathrm{BOD}_{\text {total }} ; \mathrm{BOD}_{\text {sol }}$ and VSS in the Effluent.

It is possible to observe a correlation between the behavior of the total BOD and the VSS concentration in the effluent for both pilot units in Figure 4, which proves that the loss of solids in the final effluent influenced the low efficiency in organic matter removal.

During the experiment, the $\mathrm{BOD}_{\text {total }} / \mathrm{COD}$ ratio in the influent remained, on average, at approximately 0.49 in the IAS pilot and 0.54 in the CAS pilot. This supports the conclusion that there was a relative balance regarding the biodegradability conditions of the organic loads. Figure 5 shows the behavior of this relationship as a function of the influent's volumetric organic load (VOL) due to the leachate contribution over the course of the study.

CAS Pilot

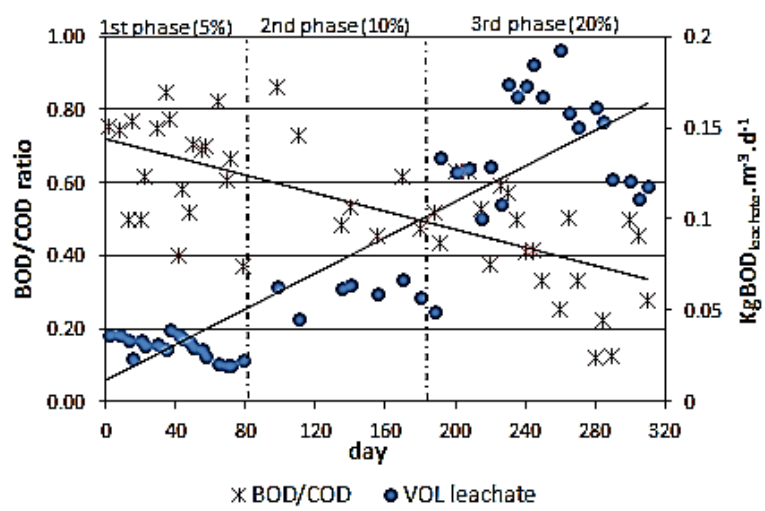

IAS Pilot

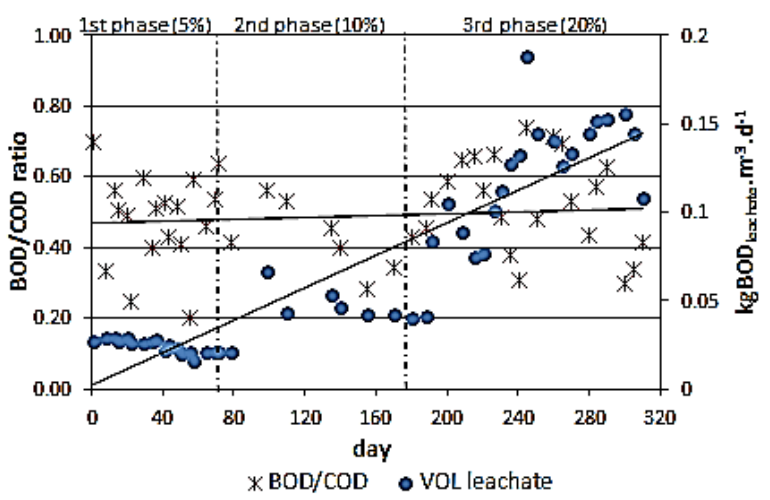

Figure 5. Correlation between VOLleachate and $\mathrm{BOD}_{\text {total }} / \mathrm{COD}_{\text {total }}$.

The conventional activated sludge (CAS) pilot unit displayed a decrease in the $\mathrm{BOD}_{\text {total }} / \mathrm{COD}$ ratio as the VOL from the leachate increased. The activated sludge with biofilm (IAS) pilot unit, on the other hand, performed in a relatively stable manner over time. It can be inferred that the suspended and adhered biomass in the IAS pilot was responsible for the performance observed since it underwent a milder impact with the load of recalcitrant compounds introduced progressively by the leachate during the study. However, this condition did not negatively impact the overall efficiency of the process. It is, therefore, possible to conclude that the introduction of leachate in decanted sewage did not cause damage to the biomass and did not affect the removal efficiency of organic compounds, as can be observed in Figure 6. 
CAS Pilot

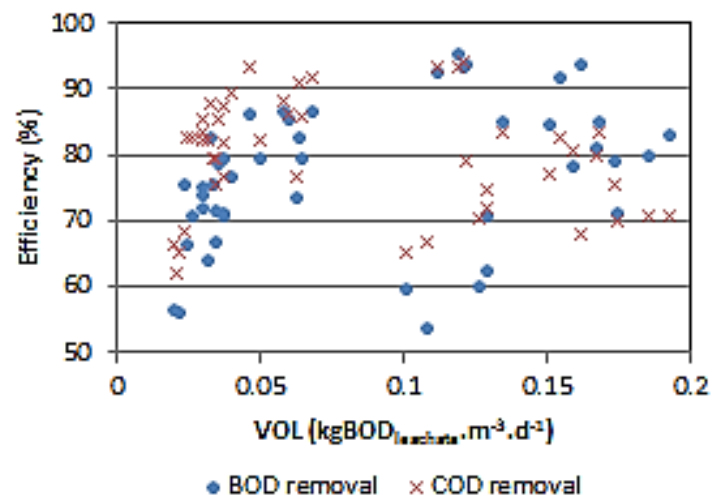

IAS Pilot

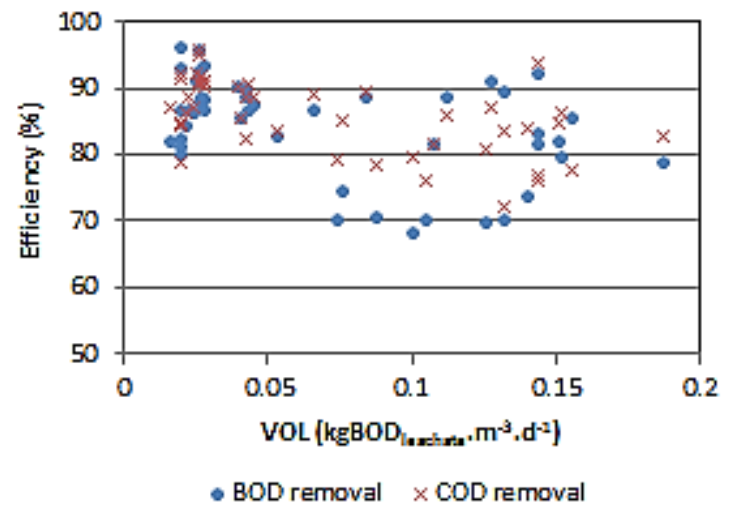

Figure 6. Correlation between VOLleachate and removal efficiency of $\mathrm{BOD}_{\text {total }}$ and $\mathrm{COD}_{\text {total }}$

By comparing the results, a slight advantage was observed in the IAS pilot unit when compared to the conventional activated sludge (CAS) pilot unit. The corresponding biomass increases of 75,43 and $55 \%$ in the aeration tank of the IAS pilot unit possibly contributed to greater robustness and stability in the removal rates expressed in terms of both $\mathrm{BOD}$ and COD, as can be verified in Table 4.

\section{Respirometric tests}

In order to evaluate the metabolic behavior of the heterotrophic bacteria in the process, respirometric tests were carried out with the suspended biomass from the CAS unit, and with the adhered and suspended biomass from the IAS pilot. The trials obtained the Total Biomass by included biomedia and Suspended Biomass by excluded biomedia. Table 6 shows the average values of the kinetic constants of growth and use of organic material for the heterotrophic bacteria, and Table 7 displays the values found in the literature $[20,27]$.

Table 6. Average Values Obtained in the Respirometric Tests

\begin{tabular}{|c|c|c|c|c|c|c|c|c|c|}
\hline \multirow[t]{2}{*}{ Phases } & \multicolumn{3}{|c|}{ CAS Pilot } & \multicolumn{3}{|c|}{$\begin{array}{c}\text { IAS Pilot } \\
\text { Suspended Biomass }\end{array}$} & \multicolumn{3}{|c|}{$\begin{array}{c}\text { IAS Pilot } \\
\text { Total Biomass }\end{array}$} \\
\hline & $\mu_{\max }$ & 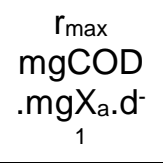 & $\begin{array}{c}\mathrm{X}_{\mathrm{a}} \\
\mathrm{mg} \cdot \mathrm{L}^{-1}\end{array}$ & $\mu_{\max }^{d^{-1}}$ & $\underset{\substack{r_{\max } \\
\mathrm{mgCOD}^{\mathrm{mgX}}}}{\mathrm{m}_{\mathrm{a}} \mathrm{d}^{-}}$ & $\begin{array}{c}\mathrm{X}_{\mathrm{a}} \\
\mathrm{mg} \cdot \mathrm{L}^{-1}\end{array}$ & $\mu_{\max } d^{-1}$ & $\begin{array}{c}\mathrm{r}_{\max } \\
\mathrm{mgCOD} \\
\operatorname{mgX}_{1} \mathrm{~d}^{-}\end{array}$ & $\begin{array}{c}\mathrm{X}_{\mathrm{a}} \\
\mathrm{mg} \cdot \mathrm{L}^{-1}\end{array}$ \\
\hline $5 \%$ & 2,8 & 6,2 & 770 & 1,6 & 3,5 & 1002 & 2 & 4,4 & 1541 \\
\hline $10 \%$ & 2,8 & 6,3 & 769 & 1,1 & 2,4 & 1000 & 1,5 & 3,3 & 1387 \\
\hline $20 \%$ & 2,7 & 6 & 846 & 1,3 & 3 & 1310 & 1,6 & 3,6 & 1600 \\
\hline
\end{tabular}

Table 7. Reference values for kinetic constants for utilization of organic material

\begin{tabular}{c|c|l}
\hline Constant & Values & \multicolumn{1}{c}{ Reference } \\
\hline$\mu_{\mathrm{m}}\left(\mathrm{d}^{-1}\right)$ & 3.7 & Lawrence et al., (1970) apud BAILEY and OLLIS, (1977). \\
& $2,4-7.2$ & Horan (1990). \\
$r_{\text {máx }}$ & $1.5-5.0$ & Metcalf \& Eddy (2003) \\
$\left(\mathrm{mgCD}_{\mathrm{L}} \mathrm{L}^{-1}\right)$ & $5.0-40.0$ & Dold et al., (1980) apud Van Haandel (2006). \\
\hline
\end{tabular}

Source: Van Haandel (1999) and Metcalf \& Eddy (2004) - adapted

Based on the results, it can be presupposed that there was no significant variation in the values of the specific growth constant, as well as in the rate of organic matter utilization by heterotrophic bacteria in the CAS process. However, it can be observed in the IAS process that both kinetic constants saw reductions of approximately $20 \%$ in the Suspended Biomass and $25 \%$ in the Total Biomass. A possible hypothesis for this occurrence refers to the substrate storage capacity conferred by the biofilm, which has the capacity of adsorbing the macromolecules present in the sewage, transporting them to the internal layers and thereby contributing to the clarification of the effluent [23]. Thus, it is assumed that the presence of recalcitrant 
compounds from the leachate contribution during each phase may have caused this reduction in the kinetic values, due to the bioaccumulation inside the biofilm. When observing the values in Table 7 for the studied constants, it should be noted that the values of $\mu_{\max }$ obtained for the heterotrophic bacteria in both processes and all phases are compatible with those found in the literature; however, the $r_{\max }$ values for the IAS process are slightly lower than those found in the literature. Another aspect to emphasize is the numerical advantage of the IAS process $X_{a}$ values when compared to the CAS process, due to the adhered biomass in the biomedia of the IAS process. In general, when comparing the kinetic behavior with the organic matter removal efficiency obtained by the two systems, there is no evidence that the leachate load contribution caused any significant changes or influence in the treatment processes. Figure 7 shows the $\mu_{\max }$ results obtained for the CAS and IAS (total biomass) processes during the study.

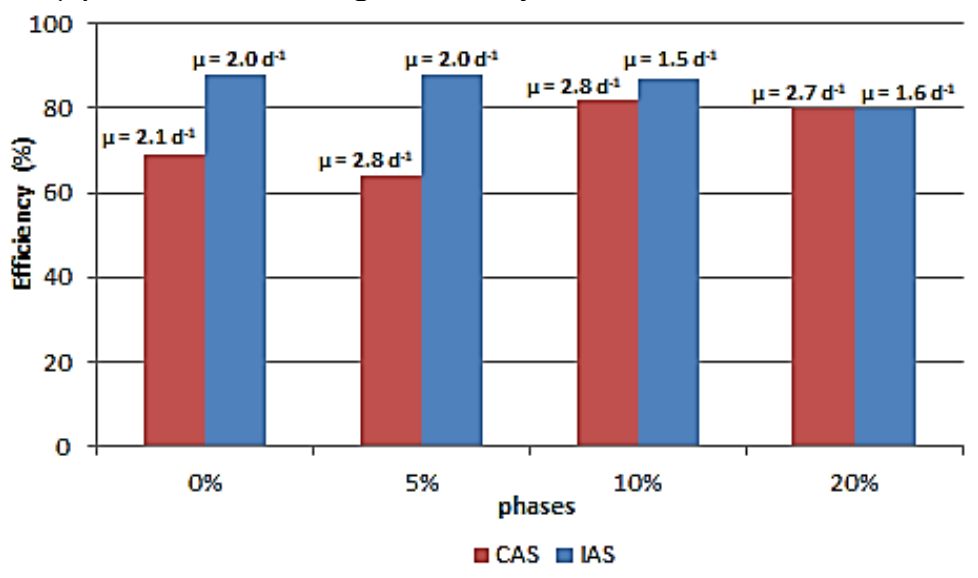

Figure 7. Correlation Between $\mathrm{BOD}_{5,20}$ Removal Efficiency and $\mu_{\max }$.

\section{CONCLUSION}

The results from the experimental investigation allowed us to conclude that the addition of leachate loads to domestic sewage is a viable alternative for the correct stabilization of this type of wastewater and that the operational control of the treatment plant is fundamental for the performance of the process. The second model displayed greater stability and operational robustness due to the presence of the adhered biomass. The expression of the percentage of the leachate contribution in the composition of the influent load allows greater clarity and a better comparison of the possible impacts caused in the treatment plants. In general, it was possible to receive up to $20 \%$ of the landfill leachate load in both systems, without jeopardizing organic matter removal. The kinetic coefficients of each phase remained steady in relation to the removal of organic matter, with minimal reduction and without negative effects on the treatment efficiency. The results reinforced the conclusion that the leachate load introduced did not cause inhibition or significant alterations to the heterotrophic metabolism.

\section{REFERENCES}

1. Bassin JP, Dezotti M. Moving Bed Biofilm Reactor (MBBR). In: Advanced Biological Processes for Wastewater Treatment. Springer, Cham, 2018; p. 37-74.

2. Campos F. Influência do Recebimento de lixiviado de aterro sanitário sobre o tratamento de esgoto em processo de Lodo Ativado e Reator Integrado de Lodo Ativado com Biofilme em Leito Móvel [master's thesis]. São Paulo: Universidade de São Paulo, Faculdade de Saúde Pública, 2014.

3. Campos F, Bueno RF, Piveli RP. Influence of the receiving of leachate from sanitary landfill on the sewage treatment in process of Activated Sludge with Mobile Biomedia. Desalination and Water Treatment, 2017; vol. 63, p. 69-77.

4. Sivic A, Atanasova N, Puig S, Bulc TG. Ammonium removal in landfill leachate using SBR technology: dispersed versus attached biomass. Water Science and Technology, 2018; 77(1),27-38.

5. Bocchiglieri MM. A influência do recebimento de chorume dos aterros sanitários da região metropolitana de São Paulo nas estações de tratamento de esgotos do sistema integrado [dissertation]. São Paulo, Universidade de São Paulo, Faculdade de Saúde Pública, 2005.

6. Klimiuk E, Kulikowska D. Organics removal from landfill leachate and activated sludge production in SBR reactors Waste Management, 2006; vol. 26, issue 10,p.1140-1147. 
7. Çecen F, Çakirolum D. Impact of landfill leachate on the co-treatment of domestic wastewater, Biotechnology Letters, 2001;vol.23,p. 821-826.

8. Ehrig HJ. Co-treatment in domestic sewage facilities. In: International Training Seminar: Management and Treatment of MSW Landfill Leachate. Cagliari: CISA, 1998.p. 1-10.

9. Diamadopoulos E, Samaras P, Dabou X, Sakellaropoulos GP. Combined treatment of landfill leachate and domestic sewage in a Sequencing Batch Reactor. Water Science and Technology, 1997; vol.36(2-3), p.61-68.

10. Mcbean E, Bleiker DE, Farquhar G. Landfill settlement and the impact on site capacity and refuse hydraulic conductivity. Waste Management \& Research, 1995; vol.13(6),p. 533-554.

11. Odegaard H, Rusten B, Westrum T. A new Moving Bed Biofilm Reactor - Applications and results. Water Science Technology, 1994; vol. 29(10-11),p.157-165.

12. Daigger GT, Boltz JP. Oxygen transfer in Moving Bed Biofilm Reactor and Integrated Fixed Film Activated Sludge Processes. Water Environment Research, 2018.

13. Water Environment Federation (WEF), Industrial Wastewater Management, Treatment and Disposal. 3a Edição Manual of Practice no. FD-3, McGraw Hill, 2008.

14. Bassin JP, Dezotti M. Moving Bed Biofilm Reactor (MBBR). In: Advanced Biological Processes for Wastewater Treatment. Springer, Cham, 2018.p. 37-74.

15. Regmi P, Thomas W, Schafran G, Bott C, Rutherford B, Waltrip D. Nitrogen removal assessment through nitrification rates and media biofilm accumulation in as IFAS process demonstration study. Water Research, 2011; vol. 45,p. 6699-6708.

16. Canziani R, Emondi V, Garavaglia M, Malpei F, Pasinetti E, Buttiglieri G. Effect of oxygen concentration on biological nitrification and microbial kinetics in a Cross-Flow Membrane Bioreactor (MBR) and Moving-Bed Biofilm Reactor (MBBR) treating old landfill leachate. Journal of Membrane Science, 2006; vol. 286(1-2), p. 202-212.

17. Welander $U$, Henrysson $T$, Welander $T$. Nitrification of landfill leachate using suspended-carrier biofilm technology. Water Research, 1997;vol.31(9),p. 2351-2355.

18. APHA/AWWA/WEF, Standard Methods for the Examination of Water and Wastewater, 21 th ed. Washington DC. 2005.

19. Catunda SYC, Deep GS, Van Haandel AC, Freire RCS. Fast online measurement of the respiration rate in Activated Sludge Systems. IEEE Instrumentation and Measurement Technology conference Bruxelas, Bélgica, 1996.

20. Van Haandel AC, Marais GVR. O comportamento do sistema de Lodo Ativado: Teoria e aplicações para projetos e operações. Campina Grande: EPGRAF, 1999, 472 p.

21. Fujii FY. Análise comparativa entre o processo de Lodo Ativado e o Reator de Biofilme de Leito Móvel na remoção de nitrogênio de esgoto sanitário [dissertação] São Paulo, Universidade de São Paulo, Escola Politécnica, 2011.

22. Minegatti DVO. Caracterização dos parâmetros de controle e avaliação de desempenho de um Reator Biológico com Leito Móvel (MBBR) [dissertation] Rio de Janeiro, Universidade Federal do Rio de Janeiro, 2008.

23. Luostarinen S, Luste S, Valentin L, Rintala J. Nitrogen removal from on-site treated anaerobic effluents using intermittently aerated Moving Bed Biofilm Reactors at low temperatures. Water Research, 2006; vol.40(8), p.16071615.

24. Andreottola G, Oliveira EL, Foladori P, Dallago L, Peterlini R, Cadonna M. Método respirométrico para o monitoramento de processos biológicos. Revista Engenharia Sanitária e Ambiental, 2005; vol.10(01), p.14 -23.

25. Water Environment Federation (WEF). Design of municipal wastewater treatment plants - Manual of Practice no. 8. Vol.1: McGraw-Hill, 2009.

26. Wiesmann U, Choi IS, Dombrowski EM, Fundamental of biological wastewater treatment. Wiley-VCH, 2007.

27. Tchobanoglous G, Burton FL, Stensel HD. Metcalf \& Eddy, Wastewater Engineering: Treatment and Reuse. 5th ed., McGraw-Hill, New York. 2014.

(C) 2020 by the authors. Submitted for possible open access publication under the terms and conditions of the Creative Commons Attribution (CC BY NC) license (https://creativecommons.org/licenses/by-nc/4.0/). 